\title{
Social Cohesion of Padang City Vocational School Students
}

\author{
Syarifah Wahidah ${ }^{1}$, Firman ${ }^{1^{*}}$ \\ 1Universitas Negeri Padang \\ *Corresponding author, e-mail: firman@konselor.org
}

\begin{abstract}
Brawls among students in various regions of Indonesia are still often the main topic in various media. Even though student brawls are not new in Indonesia, in recent years, the community has felt uneasy because brawls increasingly threaten a sense of security in the community. When explored further, a lack of student social cohesion causes student brawl. This study aims to provide an overview of the social cohesion of vocational students in Padang. This research is a descriptive study with a quantitative approach using a data collection instrument in the form of a social cohesion questionnaire with a validity greater than 0,404 and a reliability of 0,936 . The subjects of this study were vocational high school students in Padang. The subjects were chosen by simple random sampling technique. This study applied data analysis with descriptive analysis. The results of this study indicate that the students' social cohesion consists of various dimensions. Each dimension has a different percentage. Dimension Inclusion has the lowest percentage that is $10 \%$, dimension Participation as a percentage of $23 \%$, dimension Recognition and Appreciation has a percentage of $25 \%$, and dimension Sense of Belonging has the highest percentage, which is $42 \%$.
\end{abstract}

Keywords: Cohesion, Social.

\section{Introduction}

Brawls among students in various regions of Indonesia are still often the main topic in various media, both print, and social media. Even though student brawls are not new in Indonesia, in recent years, the community has felt uneasy because brawls increasingly threaten a sense of security in the community.

The Indonesian Child Protection Commission (KPAI), in its noted posted on the official KPAI website in September 2018, stated that the conditions for fighting at the National level continued to improve. In 2017 the brawl rate was $12.9 \%$, and in 218, it was 14\% (Tempo, 2018). KPAI also noted that in the past two years, there were around 202 children involved in brawls to the legal realm (Hendrian, 2018). The KPAI recorded the number of child violence cases in education, especially in the case of brawlers as many as 31 cases (19.3\%) and 23 brawl victim cases $(14.3 \%)$. In the brawl case, 74 cases are the cases of children with possession of sharp 
weapons. Also, the head of the education sector, Retno Listyarti, stated that student brawl case in 2018 reached 144 cases or 32.35\% (Intan, 2018).

The increase of brawl cases did not only occurred on a national scale but also on the provincial scale, especially in the Province of West Sumatra. The Deputy Governor of West Sumatra, Nasrul Abit, conveyed that brawls often occur in Padang even the Padang Resort Police managed to secure 27 adolescents involved in brawl action that six of them are women on May 8, 2019 (republika.co.id, 2019). The statement of the Deputy Governor of West Sumatra was proven by some news such as: On Friday, January 12, 2018 some students who partly brought sharp weapons were involved in the brawl in Padang, the brawl took place in Haji Agus Salim Sport Center and involved students of SMK Taman Siswa, SMK 5 Padang, SMK Kosgoro, SMK PGRI 6, and other schools (Covesia, 2018). On Monday, July 16, 2018, 14 vocational students in Padang were arrested by Satpol PP (civil service) Padang, 2 of them were from SMK 5 Padang (Chandra, 2018). In a brawl between high school students, which happed on Friday 2 November 2018, four students fell victim to sickle and samurai swords. This brawl occurred due to being forced by the alumni and was followed by several students who came from Kosgoro High School, SMK 8, Muhammadiyah Vocational School, Kartika Vocational School, SMK 5 and PGRI 6 Vocational School (Harian Haluan, 2018).

The brawl case has been considered something entrenched among students. Many factors cause student brawls, such as the doctrine by seniors to juniors about how to fight and who is the enemies, or simple factors such as touching on a bus, fighting over a partner, or even looks at and mock one another among the students can lead to social conflict. (Kementerian Pemberdayaan Perempuan dan Perlindungan Anak, 2017).

Social conflict is a condition where there is no unity, integrity, and cohesion in group members, and it is a bad thing in social life because, in social life, we need unity and cohesiveness between people, which is called social cohesion. Social cohesion is a condition with unity, integrity, and cohesion to keep group members staying in a community (West \& Turner, 2007). Besides, according to Arthur (2010), social cohesion is the tendency for a group or society to defend itself and unite a number of its components. Furthermore, French Commisariat General du Plan in (Andrew Norton dan Arjan de Haan, 2013) defines that social cohesion is a social process that helps instill in individuals a sense of belonging in a community and a feeling that they are recognized as members of that community.

Social cohesion is considered a characteristic of society in connection with social connections and relationships between individuals, groups of associations, and territorial units (schmitt, 2000). Several factors influence social cohesion, namely: (1) a series of efforts are required to enter into social groups to create interpersonal interest among members of one another (2) a threat from outside or competition, (3) small groups are more likely to be cohesive, dan (4) the extent of things attracted members to the group as a place to satisfy or meet personal needs (Rahmat, 2005). Sosial cohesion is a unity and good relationship between individuals and other individuals. Social cohesion becomes a problem if the relationship is shown to be mutual hostile, aggressive, and a sense of pleasure for the failure of others or groups (Yusza, Firman, \& Daharnis, 2018). 
Based on the explanation above, it can be concluded that social cohesion is the ability of individuals or groups to unite, eliminate differences, build togetherness, and support one another to achieve the goals. Social cohesion is expected to create safety and peace for members of the community, especially students.

\section{Method}

This research is descriptive research with a quantitative approach. This study aims to determine the level of social cohesion of vocational students in Padang which amounts to 14 State Vocational Schools and 25 Private Vocational Schools. The research population is vocational students in Padang. The research sample was taken by applying simple random sampling totaling 100 students from 5 different schools with consideration because this technique was carried out rancomly without considering the strata in the population. Data collection techniques were non-test techniques with social cohesion instruments in five categories of answers, which are very appropriate, appropriate, quite appropriate, not suitable, and very not suitable arranged under the conditions of students. This study applied data analysis with descriptive analysis.

\section{Results and Discussion}

Social cohesion in this study refers to an individual effort to unite and foster relationships with other individuals. Social cohesion is characterized by four dimensions: ownership, inclusion, participation, recognition or appreciation, and legitimacy (Schmitt, 2000).

A sense of belonging is an attitude of mutual understanding, honest among others, so every member feels a sense of belonging. Inclusion is an effort to build and develop an open environment without discriminating against the members because of status, condition, culture, and abilities. Recognition and appreciation is an attitude where one must respect one another among individuals; if someone succeeds, then he must be appreciated, and each member must acknowledge each other's strengths. Everyone is expected to participate in achieving group goals. The last dimension is legitimacy, in which the group gets recognition from the wider community, and if it is internal to the group, the individual must get recognition from other group members.

The results of data analysis of students' social cohesion are three categories: low, medium and high as shown in the table as follows.

\section{Table.1 The Frequency Distribution of Social Cohesion of Vocational School Students in Padang}

\begin{tabular}{|l|c|c|}
\hline Interval & Category & F \\
\hline $115-150$ & High & 17 \\
\hline $79-114$ & Medium & 65 \\
\hline $43-78$ & Low & 18 \\
\hline \multicolumn{2}{|c|}{ TOTAL } & $\mathbf{1 0 0}$ \\
\hline
\end{tabular}


Table 1 shows that out of 100 students, 17 students had social cohesion in the high category, 65 students were in the moderate category, and 18 were in a low category. The collected social cohesion data were analyzed using percentages. Based on the data analysis, the details of the social cohesion of SMK students in Padang City are as follows

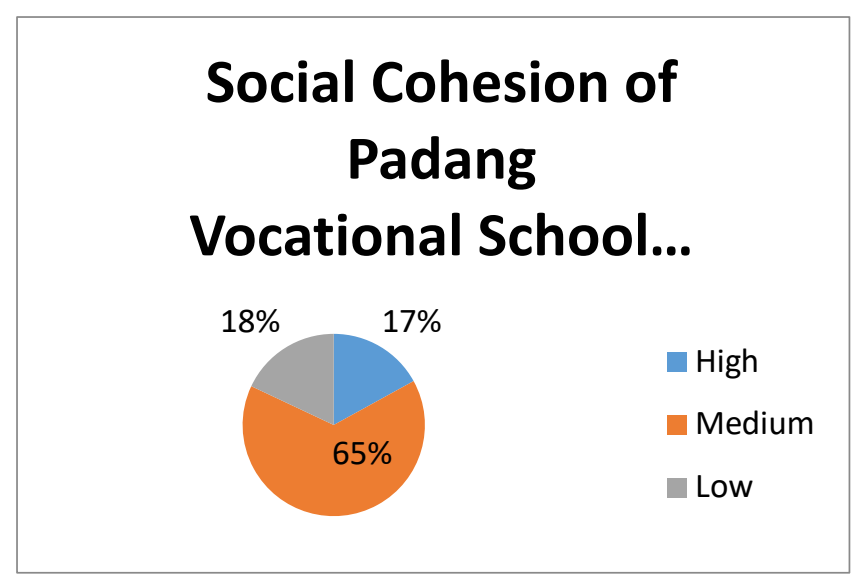

Figure 1. Percentage of Social Cohesion of Padang Vocational School Students

Based on the results of students' social cohesion percentage at the Vocational School in Padang, some of the students have a percentage with a high category of $17 \%$. Ideally, this high category should be developed in students. However, in reality, the results of the data analysis showed that $65 \%$ of the students had moderate social cohesion, and $18 \%$ had low social cohesion. Furthermore, the students' social cohesion in each dimension describes in detail in the table as follows.

Table 2. Descriptive Social Cohesion of Padang Vocational School Students in Cohesion Dimension

\begin{tabular}{|c|c|r|r|r|r|r|r|r|}
\hline \multirow{2}{*}{ Category } & \multicolumn{2}{|c|}{$\begin{array}{c}\text { Sense of } \\
\text { Belonging (SB) }\end{array}$} & \multicolumn{2}{|c|}{ Participation (P) } & \multicolumn{2}{|c|}{ Inclusion (I) } & \multicolumn{2}{c|}{$\begin{array}{c}\text { Recognition and } \\
\text { Appreciation } \\
\text { (RA) }\end{array}$} \\
\cline { 2 - 10 } & F & percentage & F & persen & F & persen & F & persen \\
\hline High & 30 & $30 \%$ & 17 & $17 \%$ & 7 & $7 \%$ & 18 & $18 \%$ \\
\hline Medium & 56 & $56 \%$ & 75 & $75 \%$ & 80 & $80 \%$ & 68 & $68 \%$ \\
\hline Low & 14 & $14 \%$ & 8 & $8 \%$ & 13 & $13 \%$ & 14 & $14 \%$ \\
\hline skor & $\mathbf{1 0 0}$ & $\mathbf{1 0 0} \%$ & $\mathbf{1 0 0}$ & $\mathbf{1 0 0} \%$ & $\mathbf{1 0 0}$ & $\mathbf{1 0 0} \%$ & $\mathbf{1 0 0}$ & $\mathbf{1 0 0} \%$ \\
\hline
\end{tabular}

Table 2 illustrates social cohesion with the percentage on each dimension of cohesion. The first, the SB dimension has the highest percentage in the high category. Second, the P dimension has the highest percentage in the medium category. Third, the I dimension has the highest percentage in the medium category. The fourth, the RA dimension has the highest percentage in the medium category. Based on the data above, it can be interpreted that the social cohesion of vocational school students in the city of Padang is partly in the high category, especially in the sense of belonging dimension. However, from the four dimensions studied, the inclusion aspect has the lowest percentage in the sense of belonging category, 
which means that vocational students still need special attention in increasing the dimension of inclusion so that with an increase in the sense of inclusion, the social cohesion of vocational students also increases.

Further description of the percentage of social cohesion in more detail is presented in the figure as follows.

\section{Dimensions of Social Cohesion of Padang Vocational School Students}

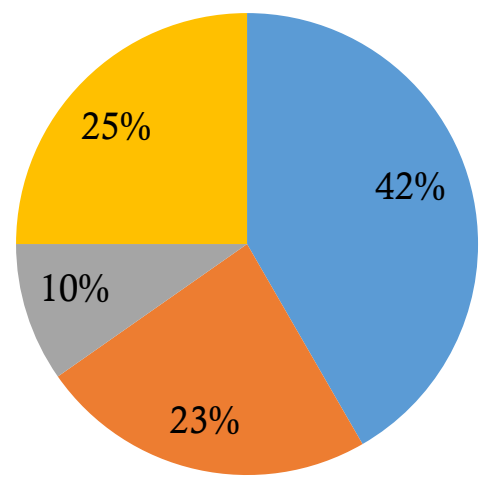

- Sense of Belonging (SB)

$\sim$ Participation (P)

Inclusion (I)

$\square$ Recognition and Appreciation (RA)

\section{Gambar 2. The dimension of Social Cohesion of Padang Vocational School Students}

The analysis of social cohesion percentage of vocational students in Padang showed that students' social cohesion consisted of various dimensions. Each dimension has a different percentage. The I dimension has the lowest percentage, which is $10 \%, \mathrm{P}$ dimension has a percentage of $23 \%$, RA dimension has a percentage of $25 \%$, and the SB dimension has the highest percentage, which is $42 \%$.

\section{Conclusion}

This research is research with vocational high school students of Padang as the research subject. The results of this study showed that most of Padang Vocational School students tend social cohesion in the moderate and even low categories. Some of the low social cohesion is on the Inclusion (I) dimension, the Recognition and Appreciate (RA) dimension, and the Participation dimension (P). Besides, the students also had high social cohesion in the Sense of Belonging (SB) dimension. The results of this study can be used as information for counselors as a basis to help students improve social cohesion to prevent negative behavior, one of which is brawl behavior, and as an effort to help develop students' self-abilities in the social field. 


\section{References}

Andrew Norton dan Arjan de Haan. (2013). Social Cohesion: Theoretical Debates and Practical Applications with Respect to Jobs.

Arthur, S. R. \& E. S. R. (2010). Kamus Psikologi. Yogyakarta: Pustaka Pelajar.

Chandra, R. (2018). Ngompas dan Tawuran, 14 Pelajar SMK Ditangkap Satpol PP Padang.

Covesia.com. (2018). Edan! Pelajar di Padang Tawuran Pakai Parang.

Harian Haluan.com. (2018). Dipaksa Alumni, Puluhan Pelajar dari 6 Sekolah Tawuran di GOR Agus Salim.

Hendrian, D. (2018). KPAI: 202 Anak Tawuran dalam Dua Tahun.

Intan, G. (2018). KPAI: Kasus Kekerasan Anak dalam Pendidikan Meningkat Tahun 2018.

Kementerian Pemberdayaan Perempuan dan Perlindungan Anak. (2017). Tawuran: Bentuk Kesalahan Remaja dalam Berinteraksi. Retrieved September 9, 2019, from KEMENTERIAN PEMBERDAYAAN PEREMPUAN DAN PERLINDUNGAN ANAK REPUBLIK INDONESIA website: https://www.kemenpppa.go.id/index.php/page/read/31/1405/tawuran-bentukkesalahan-remaja-dalam-bereksistensi

Rahmat, J. (2005). Psikologi Komunikasi. Bandung: Remaja Rosdakarya.

republika.co.id. (2019). Wagub Sayangkan Ramainya Tawuran Remaja di Kota Padang.

schmitt, R. B. (2000). Social Coheison as An Aspect of the Quality of Societies: Concept and Measurement. Journal Centre for Survey Research an Methodology (ZUMA), EuRoportin.

Schmitt, R. B. (2000). Social Coheison as An Aspect of the Quality of Societies: Concept and Measurement. In A TSER-Project Financed by the European Commission (No. 14). Mannheim.

Tempo.co. (2018). KPAI: Tawuran Pelajar 2018 Lebih Tinggi dibanding Tahun Lalu.

West, R., \& Turner, L. H. (2007). Introducing Communication Theory: Analysis and Apllication. Jakarta: salemba.

Yusza, S., Firman, F., \& Daharnis, D. (2018). Efektivitas bimbingan kelompok menggunakan permainan simulasi dalam meningkatkan kohesi sosial. Template paper indonesia. https://doi.org/10.31227/osf.io/b6wg8 